\title{
CHARACTERISTICS OF THE SPATIAL AND TEMPORAL DISTRIBUTION OF FIRE REGIME IN ONE OF THE MOST FIRE PRONE REGION OF THE RUSSIAN FAR EAST
}

\author{
Anna M. Zubareva ${ }^{1 *}$, Vladimir A. Glagolev' ${ }^{1}$ Elena A. Grigorieva ${ }^{1}$ \\ ${ }^{1}$ Institute for Complex Analysis of Regional Problems Far Eastern Branch Russian Academy of Sciences \\ *Corresponding author: anna-doroshenko@yandex.ru \\ Received: September 24 $4^{\text {th }}, 2020$ / Accepted: May 25 th 2021 / Published: July $1^{\text {st }}, 2021$ \\ https://DOI-10.24057/2071-9388-2020-159
}

\begin{abstract}
Wildfires affect the structure and distribution of vegetation all over the globe and have their own specifics in different regions. In this study, we considered the spatial and temporal distribution of fires in the Jewish Autonomous Region (JAR), which is the most fire-prone area of the Russian Far East. Using data from the Department of Natural Resources of the Jewish Autonomous Region, fires and burned areas for more than 40 years were analyzed. The average annual number of fires is near 100, and the average area of one fire is 134 hectares, which is significantly higher compared to other regions of Russia. The largest number of fires and fires with the greatest extent took place in 1975. The intra-annual distribution of fires is bimodal and depends on the climate characteristics of the region. Mapping of burning areas showed that most of the fires occurred near settlements and along roads. The main centers of fire ignition were areas with a large number of small fires (no more than 5 hectares), located within several types of locations: (1) asphalt and dirt roads, railroads and river valleys near settlements; (2) areas of former logging that have several large burned spots of more than 300 hectares; (3) plains with a high concentration of fires over a large region; and (4) small burned spots on the mountain slopes, along the field roads and small rivers. Regions with different degree of fire exposure were identified. Sedge-reed mixed grassy meadows and Agricultural land with shaded meadows are the plant formations most prone to wildfires. At the same time, more fires were detected in Cedar-deciduous forests as well as Oak and black birch forests. The findings are useful for environmental protection agencies in planning fire management strategies, optimizing the fire services and firefighting actions.
\end{abstract}

KEYWORDS: forest fire, spatial and temporal distribution, burning, plant formations, sources of fire, pyrological characteristics, Russian Far East

CITATION: Anna M. Zubareva, Vladimir A. Glagolev, Elena A. Grigorieva (2021). Characteristics of the spatial and temporal distribution of fire regime in ONE OF the most fire prone Region Of The Russian Far East. Geography, Environment, Sustainability, Vol.14, No 2, p. 74-82 https://DOl-10.24057/2071-9388-2020-159

ACKNOWLEDGMENTS: This study was financially supported by the state budget.

Conflict of interests: The authors reported no potential conflict of interest.

\section{INTRODUCTION}

Wildfires are a significant problem worldwide, affecting all aspects of the environment, including the structure, composition and distribution of vegetation (Montz et al. 2017). Every year, up to 400,000 wildfires occur worldwide and, as a result, near $0.5 \%$ of the total forest area is damaged. The wildfire danger depends on climate indicators (Sommers et al. 2012; Dupuy et al. 2020), pyrological characteristics of vegetation (Frantz et al. 2016), anthropogenic development (Zumbrunnen et al. 2012), and landscape characteristics (Noon 2003; Díaz-Delgado et al. 2004). The burn probability has been studied in many regions all over the globe: in countries of the Mediterranean - Portugal (Goncalves and Lourenco 1990; Sofia et al. 2012), Spain (Díaz-Delgado et al. 2004), Greece (Kourmpa and Tsigdinos 2020), France, Italy (Salis et al. 2016), as well as in the USA (Radke 1995; Haiganoush et al. 2016; Parisien et al. 2012), Canada (Rogeau et al. 2016), Australia (Linacre 2018; Stephens 2014), China (Yi et al. 2016; Tian et al. 2013a), and Finland (Viegas et al. 1999; Heikinheimo 1998). Although a large number of measures to combat forest fires has been taken, they continue to play an important role in forest ecosystems (Dupuy et al. 2020).

In Russia, there are more than 30000 wildfires annually, in which 2-3 million hectares of forests are damaged. Fire destroys flora, fauna, and the natural environment as a whole, causing economic and environmental damage. In the total number of fires, the Siberian Federal District is in the first place (44\% of the total number), followed by the Ural Federal District (23\%). The Far East is one of the most fire-prone regions of Russia with $4 \%$ of the total number of fires and $43 \%$ of the total burned-out area in the Russian Federation; wildfires here destroy approximately 1,112,000 hectares annually, drastically changing ecosystems of the region (Forest complex... 2005).

The fire hazard in the Far Eastern regions has not been extensively studied. The papers (Sheshukov 1982; Telitsyn1988) focused mainly on the prevention and suppression of vegetation fires in Khabarovsky Krai, comparing the characteristics of wildfires in the southern and northern regions. The studies (Glagolev 2017) on wildfire hazard prediction (Kogan and Glagolev 2014; Baranovskiy et 
al. 2017; Baranovskiy et al. 2017; Glagolev et al. 2018) discuss the wildfire regional scales, considering the number and area of fires within a certain unit of area. Forest protection agencies give the statistical number and size of fires for each year, determining the spatial distribution of each fire separately, without deep spatial analysis, nor separately identifying the re-burnt regions. As the importance of wood as an accessible building material has increased, largescale studies on the Russian Far East were carried out in the 1980s. A modern detailed analysis of fire characteristics has been made for Da Hinggan Ling prefecture, located in Heilongjjiang Province, China (Tian et al. 2013b).

Fig. 1 shows that the Jewish Autonomous Region (JAR) holds one of the leading positions in the Far Eastern Federal District in terms of the relative number of wildfires and burned area per 1 million hectares (Sheshukov et al. 2009).

The purpose of this study was to provide a review and analysis of spatiotemporal and pyrological characteristics of wildfires in the Jewish Autonomous Region. Information related to the occurrence and spatial distribution of wildfires, as well as their spatial scale can provide new information, and become a scientific basis for actions to predict and reduce wildfire risk in the region.

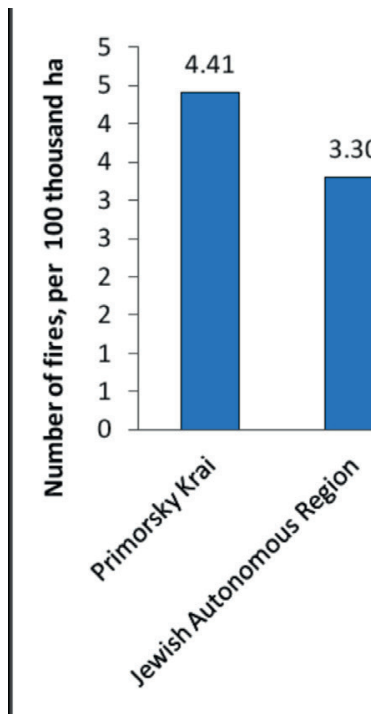

3.30
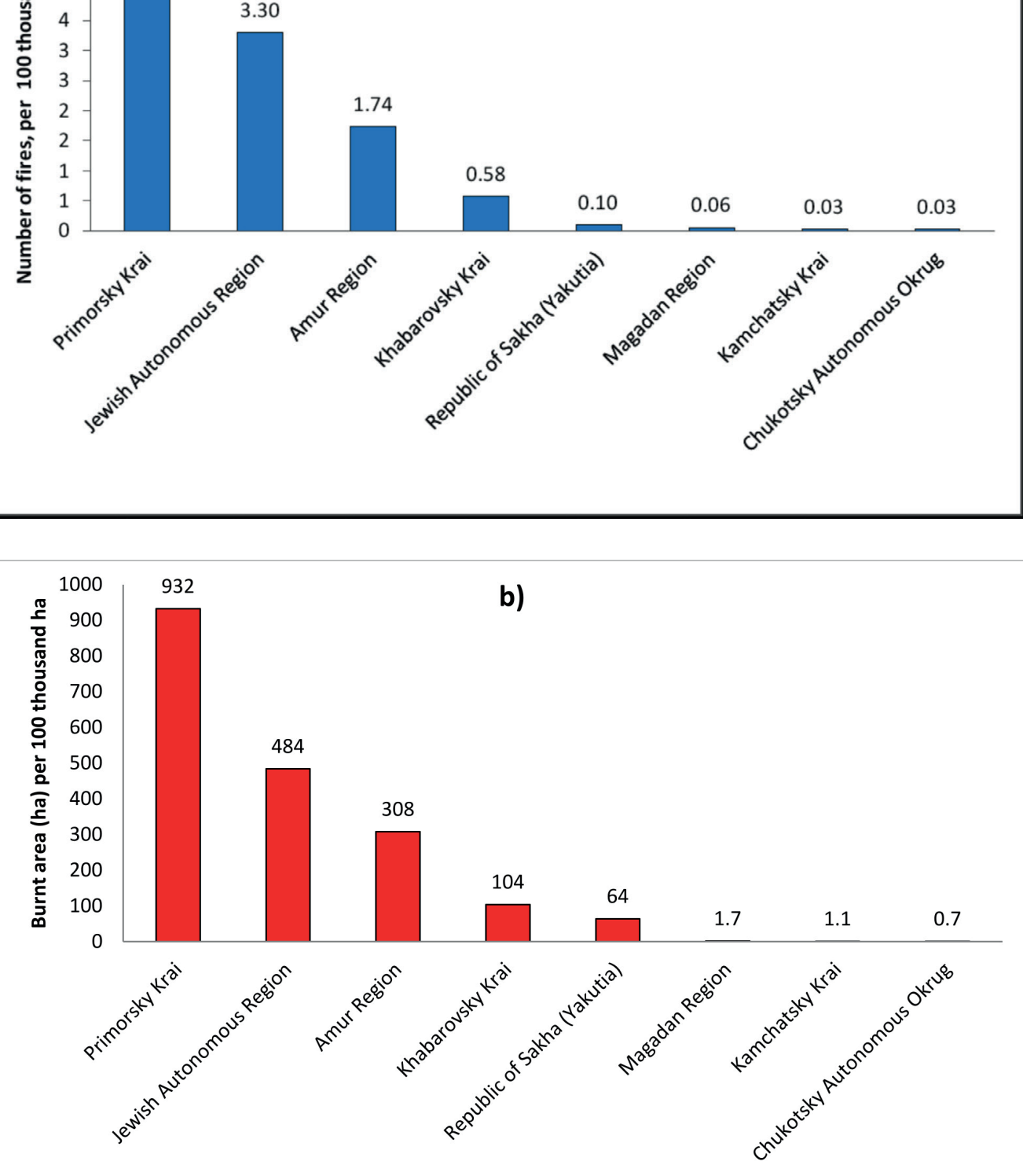

Fig. 1. Wildfires in the Far Eastern Federal District: a) number of fires; b) area covered by fires, per 100 thousand ha 


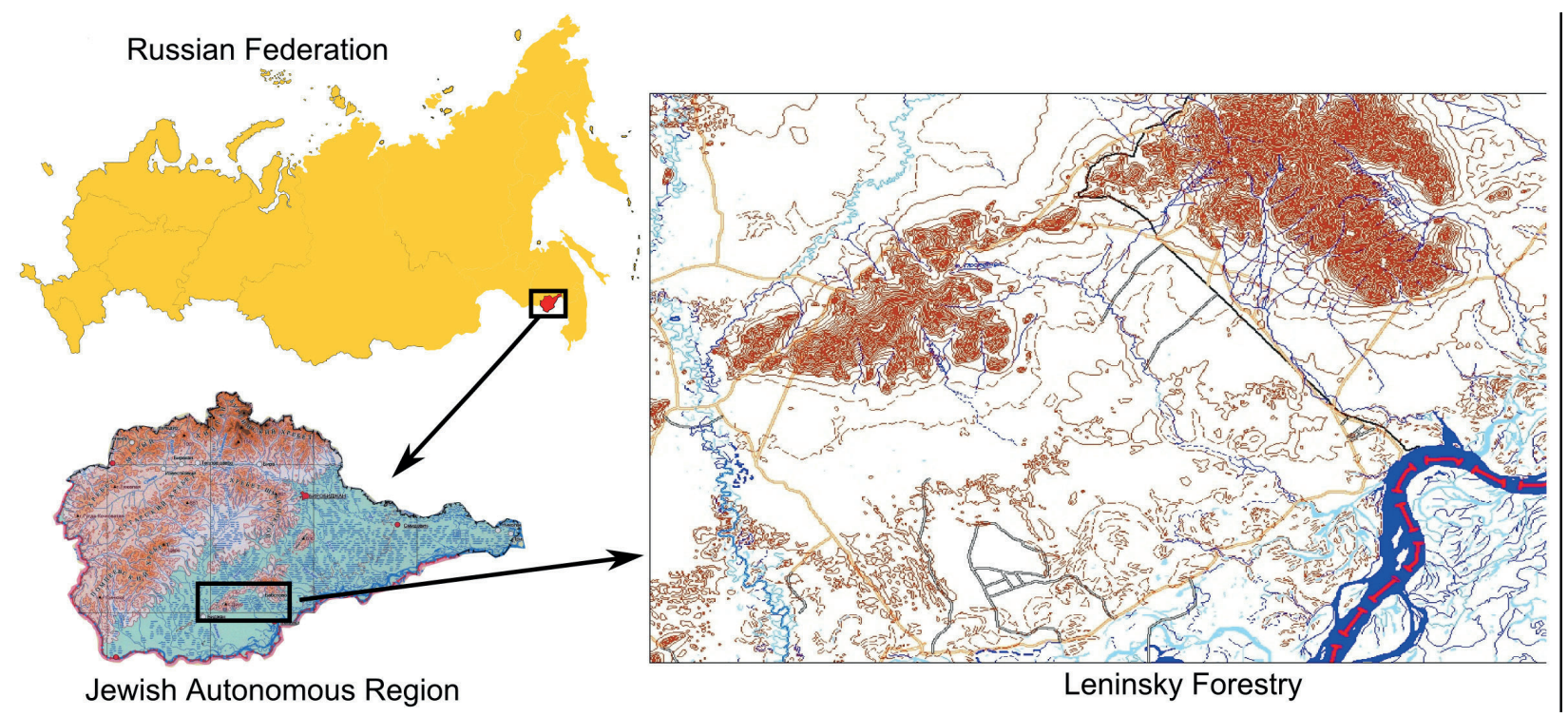

Fig. 2. Geographical location of the Jewish Autonomous Region and Leninsky Forestry unit

We selected Leninsky Forestry unit as a case study for our research on burnt areas and sources of fire. Leninsky Forestry unit is located in the southern part of the Jewish Autonomous Region, in mountainous and flat terrain. It belongs to the territory with the highest burning rate in the region. Wildfire spots here have different areas, from small (1 ha) to large (several thousand ha) ones. Most of the existing burned areas are confined to settlements and roads.

\section{Data}

We used the following data in the study: information on the number and other characteristics of wildfires from the Forestry Agency for the Jewish Autonomous Region, Ministry of Natural Resources of the Russian Federation, based on ground and aerial monitoring, for the period from 1970 to 2017. Weather data - mean air temperature and precipitation for every day - was taken from the Hydrometeorological Center of Russia (Weather of Russia 1997) and IKI RAS (Weather and detailed... 2003).
The vegetation types in the Jewish Autonomous Region were mapped by Rubtsova (2016), as shown in Fig. 3. According to the map, the main plant formations in the JAR are: thickets of cedar dwarf pine (Pinus pumila), ledum (Rhododéndron) and other alpine plants confined to the upper mountain zone; dark coniferous - fir-spruce forests (Abieti-Piceetalia) from Ayan spruce (Picea jezoensis) and white fir (Ābies nephrolēpis); larch-spruce and sprucelarch forests of mountains and intermountain valleys; spruce-fir and fir-spruce with cedar (Pinus koraiensis) and broad-leaved species; white birch (Betula alba) and aspenwhite birch forests with conifers, broad-leaved species and derivative forests on mountain slopes; broad-leavedspruce-cedar forests (Quercetea mongolica) or northern cedar forests; broadleaf mixed mixed-breed forests; forests and woodlands of Mongolian oak (Quercus mongolica); small-leaved forests and woodlands on plains and in river valleys, meadow and swamp vegetation (Rubtsova 2016).

Black-birch oak-larch woodlands in combination with erniks (low-growth bush forest) and willow thickets, White birch forests along with Oak and black birch forests dominate in Leninsky Forestry.

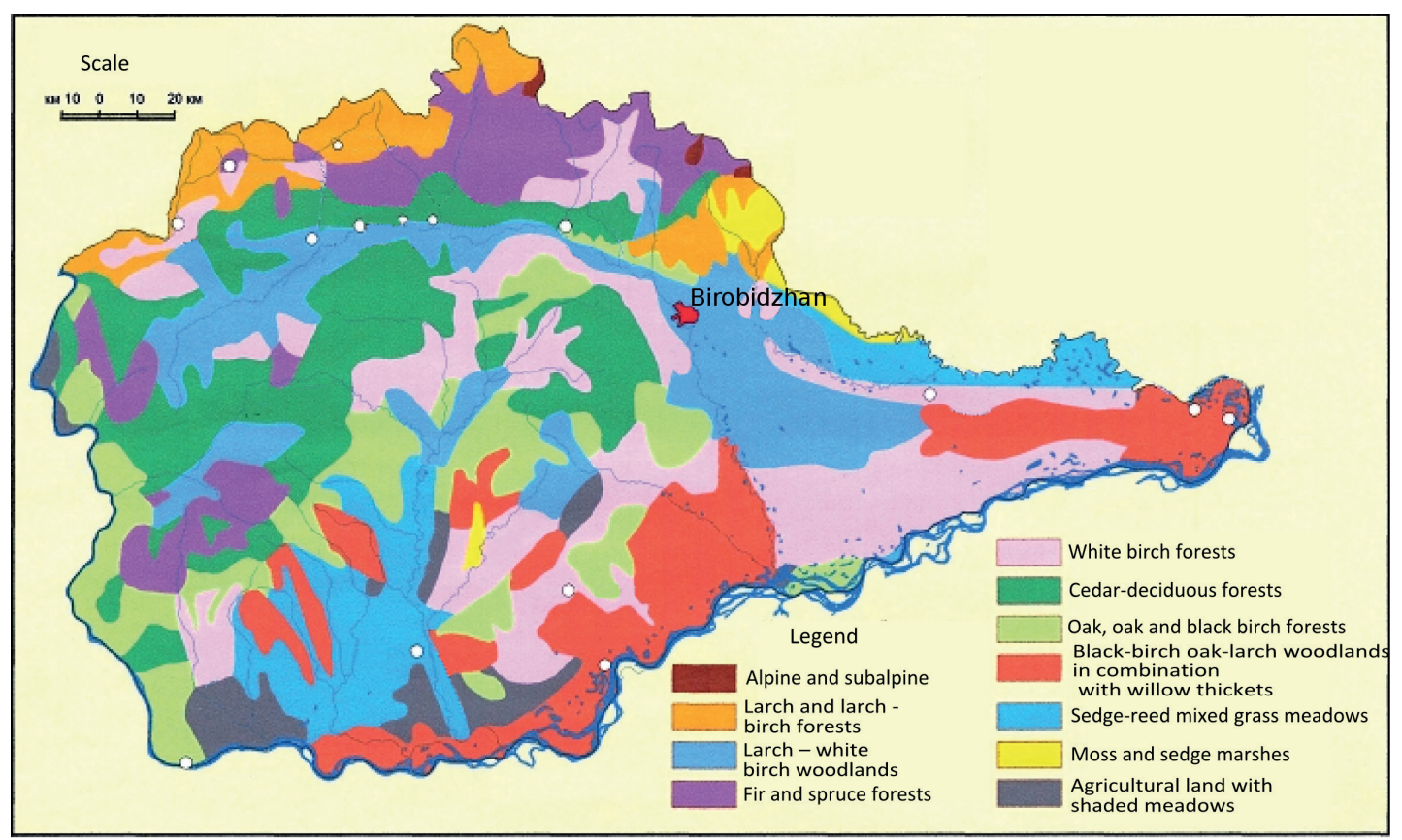

Fig. 3. Vegetation formations in the Jewish Autonomous Region (Rubtsova 2016) 


\section{Research Methodology}

The methodological approach of our study with the main structural steps is presented in Figure 4.

Firstly, the position of the region in the system of pyrological zoning of Russia is determined using the classification proposed by Dichenkov (1997). Under this classification, all regions in Russia are divided into 7 classes of large fire probability, from class I (below average) with a 10\% probability, to VII (the highest level) with 100\% fire probability (Dichenkov 1997).

At the second step, we estimate the current efficiency of vegetation combustion looking at fire and weather statistics: the number and area of the wildfires, their spatial distribution and sources of origin, along with mean air temperature and precipitation.

Third, the structure of vegetation is considered using the map of plant formations (Rubtsova 2016). This includes calculating the area of each plant formation based on its distribution in GIS «Inventory Map of the burned areas of the Jewish Autonomous Region». GIS was created in Maplnfo Professional 6.0 by researchers at the Laboratory of regional geoecological studies at ICARP FEB RAS (Doroshenko and Kogan, 2008; Zubareva 2016).

At the next step pyrological characteristics of the plant formations as the burning subject are described. The class of fire hazard of vegetation is determined using the method of Starodumov (1965). In this classification, the Far Eastern plant communities are divided into five classes according to the degree of fire danger. The I Class is characterized by a very high fire hazard, the predominance of grass-root fires throughout the fire-dangerous period, and upper fires in dry periods. Sometimes fire can occur at a low value of Nesterov's fire hazard indicator. The $V$ Class is characterized by a very low fire hazard, with the predominance of fires only after a long drought (Starodumov1965).
Last, we applied the Combustion Index (CI) of plant formations (Sofronov and Volokitina 1990), calculated as the ratio of the number and area of fires per 100 thousand hectares (Table 1).

The data obtained as a result of a structured chain of methodological research allows us to comprehensively characterize the number, size, spatial and temporal distribution of fires, and their pyrological characteristics in the study area.

\section{RESULTS}

In the pyrological zoning system of the Russian Federation, the area of JAR belongs to the Ussuriysk pyrological region (Sofronov and Volokitina 1990), which is characterized by 1.7 fires per 100000 hectares. The relative fire area is 213 hectares per 100000 hectares; the Combustion Index, which indicates the number of fires divided by their total area per unit, is 6.2 (Increased grade), the average fire area is 128 hectares (Sofronov and Volokitina 1990). According to the probability of large fires, out of the existing seven classes, the region belongs to the VII Class with a 100\% likelihood of annual fire occurrence (Dichenkov 1997).

Wildfire and weather statistics. Our analysis of the wildfires statistics showed that the maximum number of fires happened in 1970 and 2009, while the maximum area covered by fires was in 1976 (Fig. 5).

We mapped the burned areas in Leninsky Forestry unit as a case study based on fires data for the period from 2010 to 2017 (Fig. 6). Analysis of this map shows that most wildfires are distributed along settlements, roads and rivers. The main fire-prone locations can be divided into four types: (1) areas with a large number and small size of burners (not more than 5 hectares), located along asphalt and dirt roads, railroads and river valleys near settlements; (2) areas of former logging in the mountains that have several large burned spots of more than 300 hectares; (3)

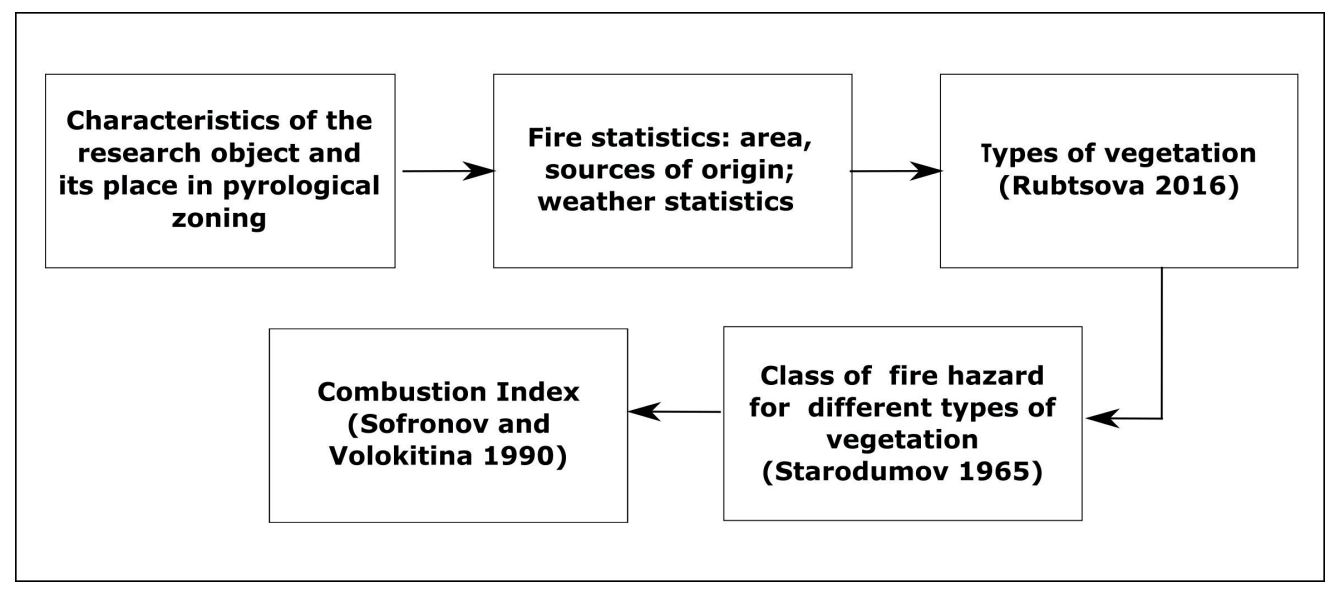

Fig. 4. Research methodology

Table 1. Assessment of the actual burning and Combustion Index (Sofronov and Volokitina 1990)

\begin{tabular}{|c|c|}
\hline Actual burning (grades) & Combustion Index \\
\hline Low (I) & $<0.7$ \\
\hline Moderate (II) & $0.8-2.5$ \\
\hline Increased (III) & $1.6-8.5$ \\
\hline High (IV) & $8.6-26.0$ \\
\hline Very high (V) & $>26.1$ \\
\hline
\end{tabular}




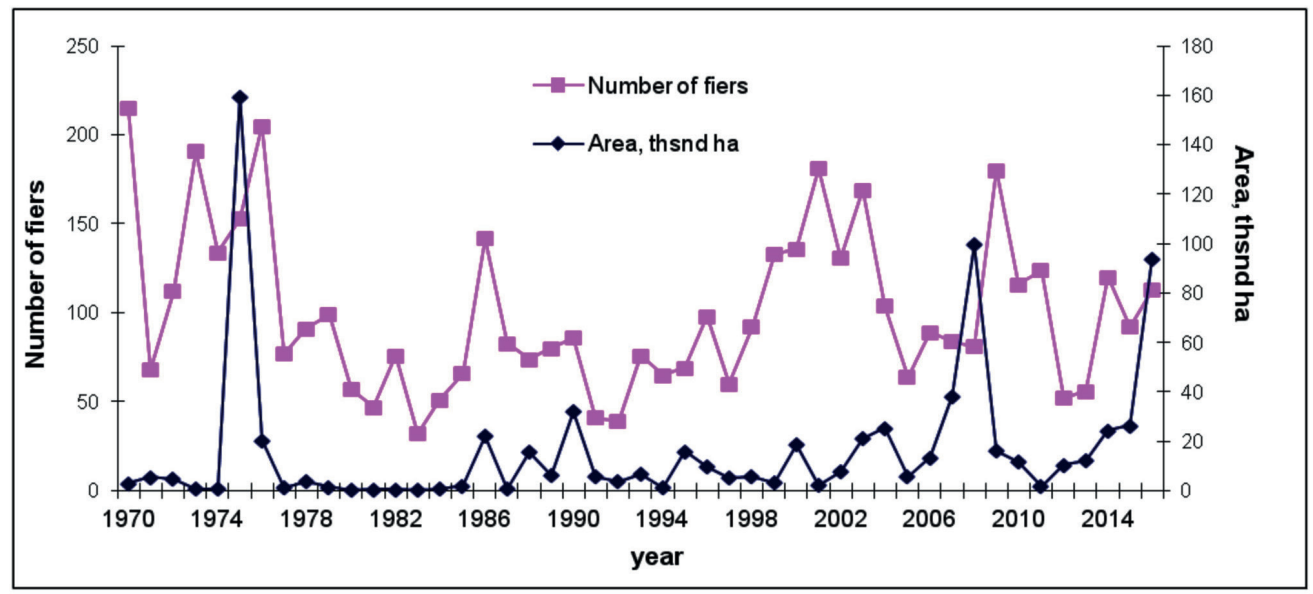

Fig. 5. The number and area of fires in the Jewish Autonomous Region, 1970-2017

plains with a high concentration of fires over a large region of more than 1000 hectares; and (4) small burned spots in mountain slopes along field roads and small rivers, where few fires are found with a small size of less than 10 hectares.

Considering the climate data in conjunction with the intra-annual fire dynamics, it is possible to determine their relationship and identify the fire hazard period within the year (Fig. 7). The largest number of fires is observed in spring. First, this period is characterized by the most favorable weather for ignition of combustible plant materials as precipitation is scarce (Grigorieva and de Freitas 2014); and second, young vegetation appears later in spring. In autumn, there are fewer wildfires and they spread less due to the relatively high precipitation.

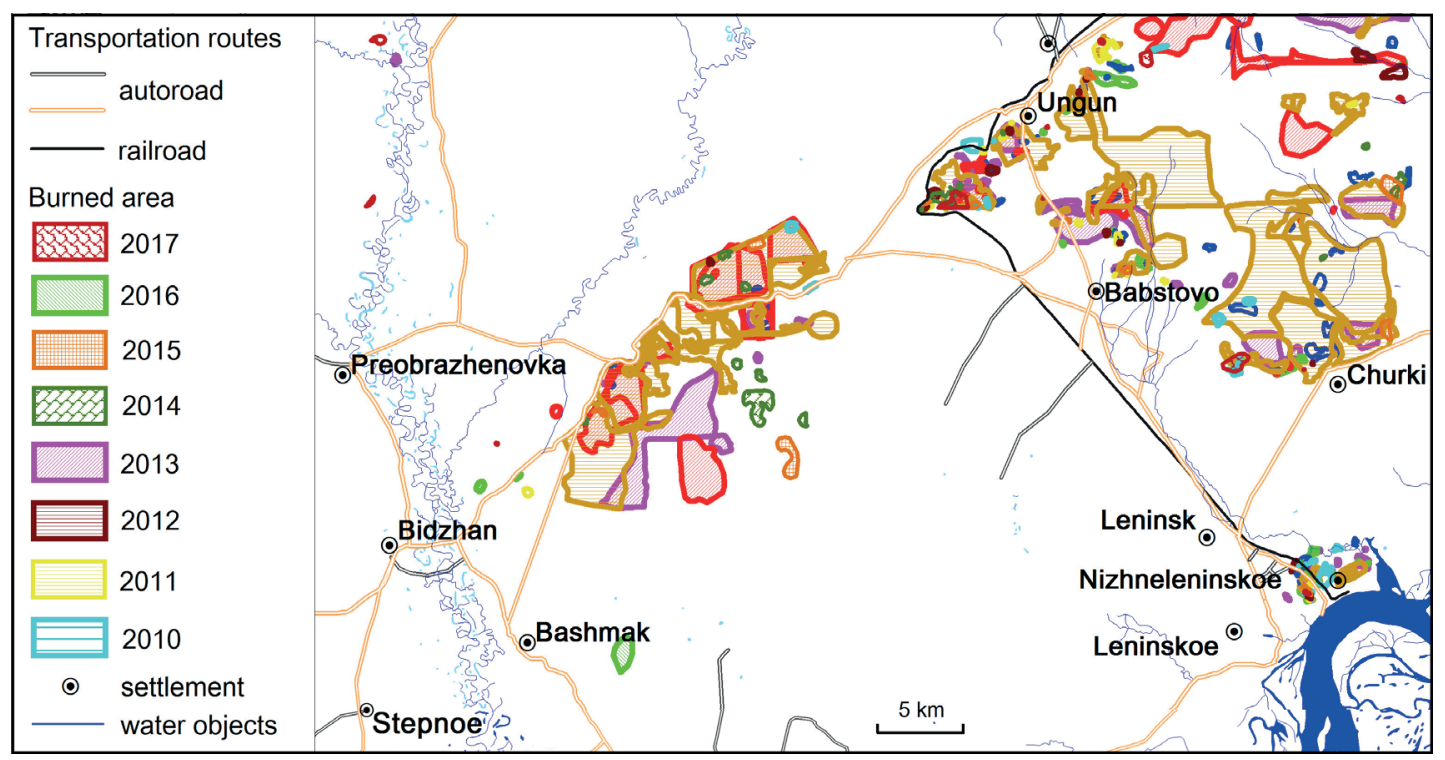

Fig. 6. Fragment «Inventory Map of the burned areas in the Jewish Autonomous Region (2010-2017)» for Leninsky Forestry unit

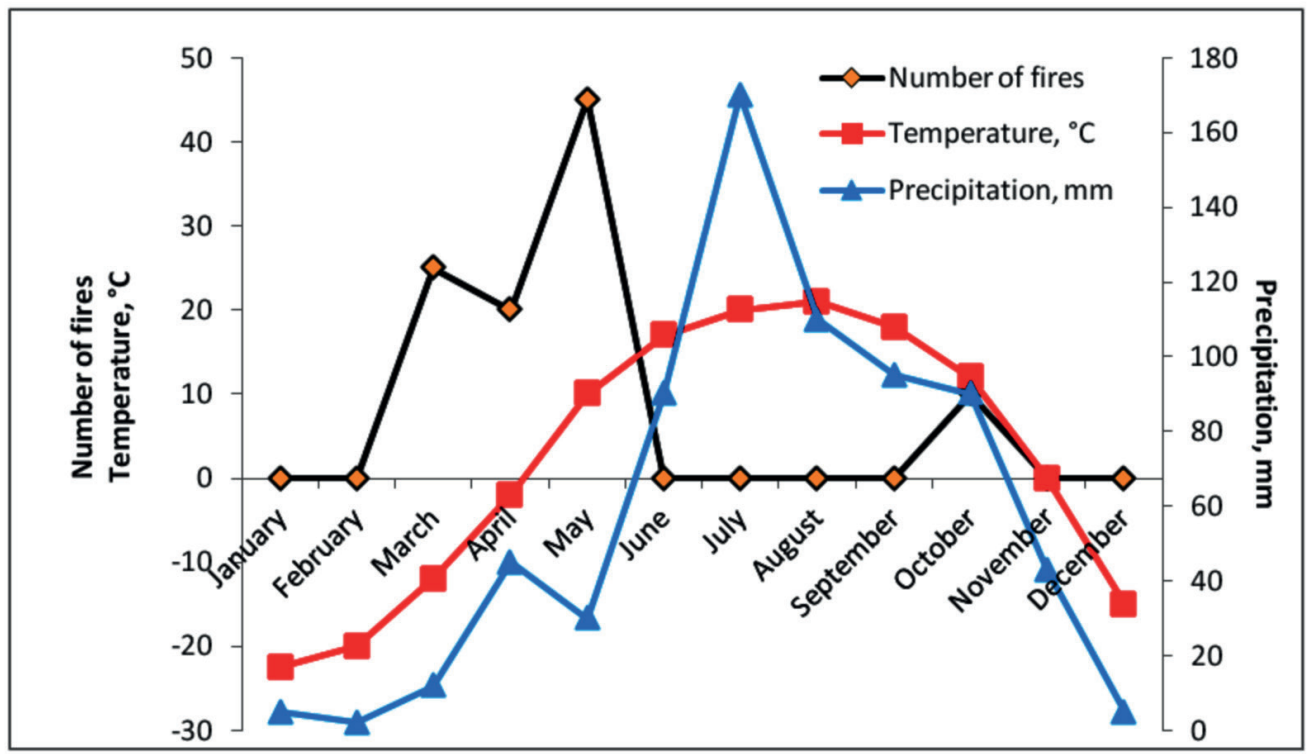

Fig. 7. The influence of climate on the intra-year dynamics of wildfires in the Jewish Autonomous Region 
Based on statistical data, we show that the majority of fires are caused by human activity; however, there is also a high proportion of fires for which the source of origin is not determined (Fig. 8).

Structure of vegetation. Table 2 shows that the white birch forests are most prevalent in the region. For the most part of the region, they form a secondary vegetation type after disturbances.

The largest fire areas are found in Sedge-reed mixedgrass meadows and Black-birch oak-larch woodlands in combination with erniks (low-growth bush forest) with willow thickets.

Pyrological characteristics of the plant formations. Class of fire hazard for different types of vegetation shows that Sedge-reed mixed grassy meadows, Agricultural land with shaded meadows (I Class of fire hazard), and Cedardeciduous forests, along with Oak and black birch forests (II Class of fire hazard) are the most fire-hazardous vegetation formations (Table 1). As a whole, they cover near $40 \%$ of the region. Moss and sedge marshes as well as Alpine and subalpine have the lowest class of fire hazard (V), covering $2 \%$ of the region (Table 1 ).

Combustion Index. The calculation of the Combustion Index in the plant formations per 100 thousand ha according to the method by (Sofronov and Volokitina 1990) is shown in Table 2. Cedar-deciduous forests together with Oak and black-birch forests are the most flammable. Moss and sedge swamps, Agricultural land with shady meadows and Sedge-reed mixed grasslands are the least prone to fires. The calculation of the combustion of these plant formations indicates that not always the most firehazardous formations are subject to the highest level of combustion. A significant number of fires are also observed in Larch and larch-birch forests (IV Class of fire hazard) and White Birch forests (III Class of fire hazard).

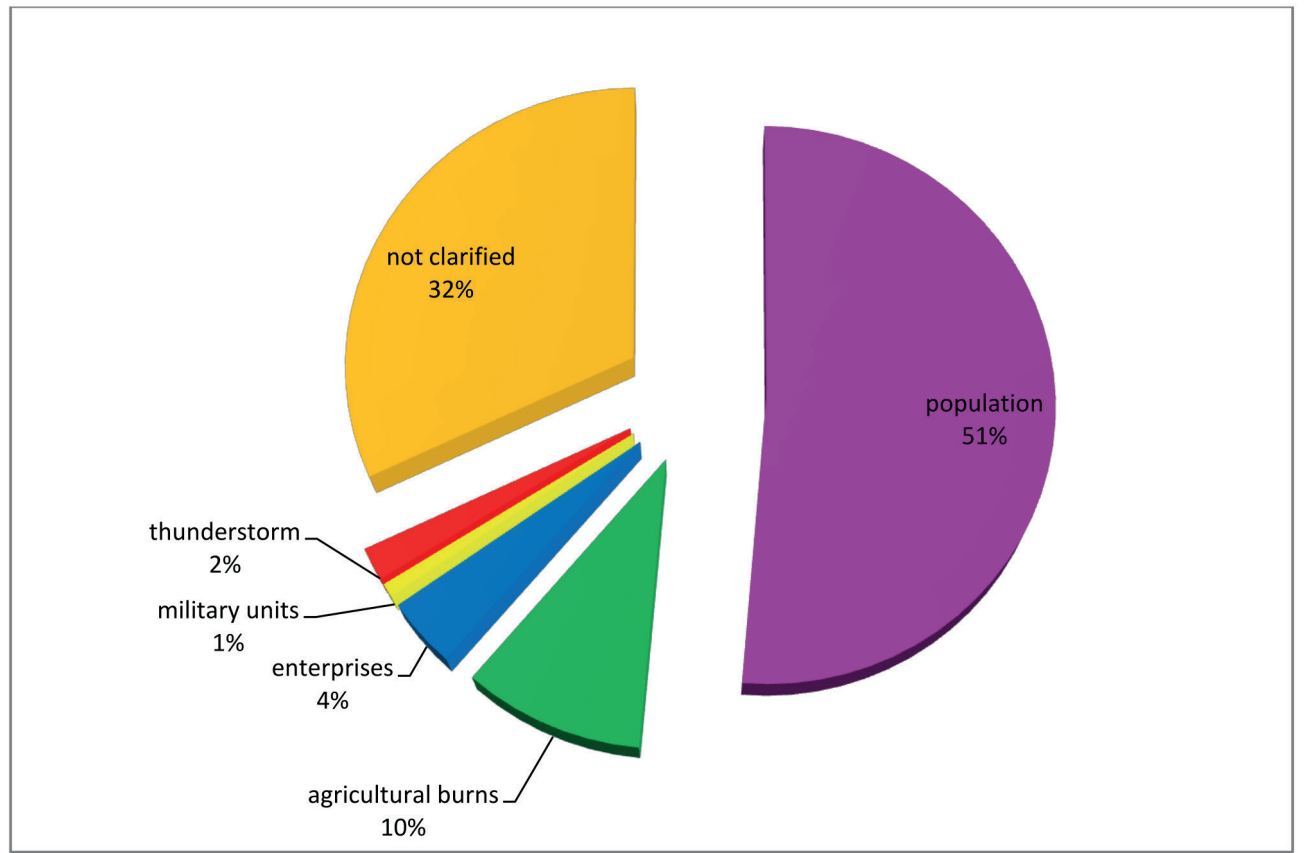

Fig. 8. Sources of fires in the Jewish Autonomous Region, 2013-2017

Table 2. Fire and fire hazard of plant formations in the Jewish Autonomous Region

\begin{tabular}{|c|c|c|c|c|}
\hline № & Plant Formation & Percent of the total area, \% & Vegetation fire hazard class & $\begin{array}{c}\mathrm{Cl} \text { : number of fires per } 100 \\
\text { thousand ha }\end{array}$ \\
\hline 1 & Alpine and subalpine & 0.21 & V & 0.00 \\
\hline 2 & Larch and larch - birch forests & 6.47 & IV & 4.00 \\
\hline 3 & Larch - white birch woodlands & 13.76 & IV & 2.50 \\
\hline 4 & Fir and spruce forests & 9.45 & III & 2.19 \\
\hline 5 & White birch forests & 16.16 & III & 3.58 \\
\hline 6 & Cedar-deciduous forests & 15.37 & $\|$ & 5.07 \\
\hline 7 & Oak and black birch forests & 12.03 & $\|$ & 4.39 \\
\hline 8 & $\begin{array}{l}\text { Black-birch oak-larch woodlands in } \\
\text { combination with erniks (low-growth } \\
\text { bush forest) and willow thickets }\end{array}$ & 13.28 & IV & 1.13 \\
\hline 9 & Sedge-reed mixed grassy meadows & 7.86 & । & 0.88 \\
\hline 10 & Moss and sedge marshes & 1.86 & V & 0.00 \\
\hline 11 & Agricultural land with shaded meadows & 3.52 & । & 0.50 \\
\hline
\end{tabular}




\section{DISCUSSION}

\section{Spatial and temporal distribution of wildfires}

Fire is a major factor in the destruction of natural landscapes. The relative influence of various pyrological factors varies across global regions. Studies of fire regimes are important for understanding fire interference and for adopting a scientific approach to fire management.

In our analysis, we found that the mean annual number of fires over the study period was near 100, which is significantly higher than in other regions of Russia. For example, Kurbatsky and Tsvetkov (1986) estimated 5 fires for Koryaksky and 33 fires for Komi-Permyatsky Autonomous Districts, 13 - for AginskyBuryatsky Autonomous District, 2 - for the Republic of Adygea, and others (Kurbatsky and Tsvetkov 1986). However, this is less than half of the number of fires in the neighboring province of Heilongjiang in China (Tian et al. 2013a, 2013b). The average area of a single fire in the Jewish Autonomous Region is 134 hectares. Near the border with China, province of Heilongjiang, this area is 1167 hectares (Tian et al. 2013a, 2013b).

The largest number of fires in the Jewish Autonomous Region was registered in 1970, 1973, 1975, 2001, 2005, and 2009; the wildfires had the largest area in 1976, 2009, and 2017. During these years, severe droughts were observed, and the mean precipitation during the fire hazard period did not exceed $70 \mathrm{~mm}$.

The areas with the largest concentration of small fires are located in the regions of transport accessibility, which allows them to be detected and localized promptly. Areas with large fires (more than 1000 ha) are found in mountainous areas, where early localization and elimination of fires are difficult due to their remoteness and difficult communications. On plains distant from the main transport routes, fires acquire large areas because terrain features allow the ignition to spread over. This distribution of lands affected by the pyrological factor is typical for the regions of new development, which is the entire Far East of the Russian Federation in general, and the Jewish Autonomous Region, in particular.

The intra-annual distribution of fires is bimodal, which is similar to the areas of the same nature in China (Tian et al. 2013a, 2013b). Most of the forest fires occur in spring (April, May) (65\%), with May having the highest rate (45\%). The fire risk period in the JAR is 214 days. The high fire danger of the spring period is explained by short, snowy winters and fast melting of the snow, as well as by increasing temperature and low precipitation, which creates favorable conditions for the ignition of combustible plant materials. The second peak period of forest fires is from September to November (35\%). The most fire hazardous month in autumn is October. In autumn, dried vegetation is easily ignited even when it is raining. Cedar-deciduous forests and Oak, oak and black birch forests are the plant formations most exposed to fire (Table 2).

\section{Natural and other sources of fire ignition}

The dynamics of forest fires in recent years makes it possible to identify factors contributing to the emergence of fire, the degree of influence of these factors is shown in the following sequence: 1) population; 2) forest fires; and 3) enterprises and organizations. The main source of forest fires is of anthropogenic origin, which in some years accounts for more than $90 \%$ of all fires. Therefore, it is necessary to improve the awareness of residents about the prevention of forest fires and to encourage the local population to participate in management activities and elimination of fires.
The smallest impact on the occurrence of fires in the Jewish Autonomous Region is exerted by natural sources of ignition, named as «dry thunderstorms». This is explained by the fact that the greatest thunderstorm activity falls on the less flammable pre-monsoon period when the combustion materials are sufficiently moistened.

A large number of fires with an unexplained source of origin might be associated with certain legal and practical difficulties in identifying the perpetrators of forest fires. In the forest, given the specificity of the object of burning and the absence of witnesses, it is often not possible to identify evidence that unequivocally confirms the guilt of the detainee, even at the site of the fire.

The sources of fires in forests include the activities of forest users, primarily loggers, collectors of berries, mushrooms, ferns, hay, and medicinal plants, and tourists. A significant source of fire is associated with all types of transport that cross forest tracts, since their fuel, when exposed to heat, ignites combustible plant materials. In the spring and autumn, agricultural organizations and the population deliberately burn old grass in their hayfields; these burns often turn into forest fires.

\section{Pyrological characteristics of the plant formations and their Combustion Index}

White birch forests are the most widespread plant formations. Cedar-deciduous forests and Larch - white birch woodlands cover over $45 \%$ of the Jewish Autonomous Region. The most prone to fire vegetation formations with Classes I-II of fire hazard make $40 \%$ of the area and include Cedar-deciduous forests, Oak and black-birch forests, Sedge-reed mixed grassy meadows, Agricultural land with shady meadows. The formations in which the fires are most frequent are White birch forests, Cedar-deciduous forests, Oak and black - birch forests, Larch and larch - birch forests. The area most prone to fires covers approximately 50\% of the Jewish Autonomous Region. It is worth noting, that the combustion of plant formations does not always correspond to their fire hazard class. For example, a high Combustion Index is found for Larch and larch-birch forests (Class IV of fire hazard) and White birch forests (Class III). At the same time, there are practically no fires in Sedge-reed mixed grassy meadows and Agricultural land with shaded meadows - plant formations with Class I of fire hazard.

The study has some limitations, one of which is that it was based on ground and air patrol observation data only. Fires are mainly detected by air patrols (approximately 65 $\%)$. Ground fire protection services detect near 30\% of fires. Satellites register no more than $5 \%$ of fires due to frequent cloudiness in the region. The reason we cannot use satellite imagery data is the large number of cloudy days observed in the study area during the fire hazard period, especially in autumn. The MODIS satellite takes low-resolution images $(250 \mathrm{~m})$, therefore we cannot fully detect the location of a fire and estimate its area. Satellite images do not provide an opportunity to characterize the type of fire and fully determine the damage caused to the forest fund. They can also overestimate the area of fires as they capture the heat flux that is reflected in heated soil and smoke (Bartalev et al. 2017).

\section{CONCLUSIONS}

The burning rate in the Jewish Autonomous Region was studied over the past 40 years, compared with other regions of the Russian Federation and neighboring countries (Chinese provinces). The previously compiled 
«Inventory Map of Burners» was supplemented with contemporary data.

Aerial monitoring was used as the main instrument for detecting forest fires in the Jewish Autonomous Region, and this method makes it possible to find most of the fires in forest areas. The intra-annual distribution of fires has a bimodal character, which is caused by the climate characteristics, forming the conditions for the ignition of combustible plant materials.

To build an effective fire control policy for vegetation, it is necessary to know the reasons for fire occurrence. In this regard, the main cause of fires is human activity, and the main areas of ignition are within the locations of the anthropogenic load. Ignitions in these areas are frequent but small in size. The size of burnt areas increases significantly, whereas the number of burns decreases with increasing distance from the location of human impact.

In the future, in order to carry out a comprehensive pyrological zoning of the Jewish Autonomous Region, an assessment of the natural and anthropogenic fire hazard is planned. This assessment will help to identify areas with varying degrees of fire exposure and should be considered when planning the fire management strategy and optimizing the organization of the fire service.

\section{REFERENCES}

Baranovskiy N.V., Barakhnin V., Yankovich E. (2017). GIS-Technologies and mathematical simulation as tools for lightning-caused forest fire danger prediction CEUR Workshop Proceedings, 1839, 2-15, DOI: 10.1117/12.2241670.

Baranovskiy N.V., Kogan R.M., Glagolev V.A., Zubareva A.M. (2017). Grassland fire spread simulation using NDVI data. In Proc. SPIE 10466,

23rd International Symposium on Atmospheric and Ocean Optics: Atmospheric Physics, 104663B, DOl: 10.1117/12.2286782.

Bartalev S.A., Stytsenko F.V., Khvostikov S.A., Lupyan E.A. (2017). Methodology for monitoring and predicting pyrogenic forest destruction based on satellite observation data. Current Problems in Remote Sensing of the Earth from Space, 14(6), 176-193, DOI: 10.21046/2070-74012017-14-6-176-193.

Díaz-Delgado R., Lloret F., Pons X. (2004). Spatial patterns of fire occurrence in Catalonia, NE, Spain. Landscape Ecology 19 (7), 731-745,

DOI: 10.1007/s10980-005-0183-1.

Dichenkov N.A. (1997). Assessment of the risk of large-scale forest fires. Forestry, 4, 46-48. (in Russian).

Doroshenko A.M., Kogan R.M. (2008). Analysis of the spatial distribution of forest fires on the territory of the Jewish Autonomous Region. Bulletin of the Tomsk State University, 311, 172-177 (in Russian).

Dupuy J.I., Fargeon H., Martin-StPaul N. et al. (2020). Climate change impact on future wildfire danger and activity in southern Europe: a review. Annals of Forest Science, 77, 35, DOI: 10.1007/s13595-020-00933-5.

Forest complex of the Far East of Russia: an analytical review (2005). A.S. Sheinghous (Ed.). Vladivostok, Khabarovsk, 160 (in Russian).

Frantz D., Stellmes M., Röder A., Hill J. (2016). Fire spread from MODIS burned area data: obtaining fire dynamics information for every single fire. Int. J. Wildland Fire, 25(12), 1228-1237, DOI: 10.1071/WF16003.

Glagolev V. (2017). Method foe prediction of the initiation and distribution of herbal fire. Technology of technospheric security, 4(74),

132-140 (in Russian).

Glagolev V.A., Zubareva A.M., Grigorieva E.A. (2018). Grassfire forecast at agricultural lands in Jewish Autonomous Region. Regional Problems, 21, 3(1), 93-97, DOI: 10.31433/1605-220X-2018-21-3(1)-93-97.

Goncalves Z.J., Lourenco L. (1990). Meteorological index of forest fire risk in the Portuguese mainland territory Proceedings of the international conference on forest fire research, Coimbra, 7, 1.

Grigorieva E.A., de Freitas C.R. (2014). Temporal dynamics of precipitation in an extreme mid-latitude monsoonal climate. Theor. Appl.

Climatol., 116(1), 1-9, DOI:10.1007/s00704-013-0925-x.

Grigorieva E.A., Kogan R.M. (2010). Pirological characteristic of climate at the southern part of the Russian Far East. Regional Problems, 13(2), 78-81.

Heikinheimo M. (1998). Renewing the system for forest fire risk assessment at the Finnish Meteorological Institute International Forest Fire News, 18, 65-67.

Weather of Russia - weather forecast, actual weather conditions (1997). Weather archive. http: //meteo.infospace.ru [20.05.2019]

Weather and detailed weather forecast from the Hydrometeorological Center of Russia (2003). Factual data. http://meteoinfo.ru

[20.05.2019]

Kogan R.M., Glagolev V.A. (2014). Features of fire-dangerous seasons in the Khabarovsk Territory and the Jewish Autonomous Region.

Fundamental Research, 9(7), 1549-1553. (in Russian).

Kourmpa E., Tsigdinos S. (2020). Detection of fire-prone areas in Attica region integrating urban and transport aspect. Geography,

Environment, Sustainability, 13(3), 84-89, DOl: 10.24057/2071-9388-2019-148.

Kurbatsky N.P., Tsvetkov P.A. (1986). Protection of forests from fires in areas of intensive development (for example, KATEK). Krasnoyarsk,

146. (in Russian).

Linacre E. Predicting bushfires in Australia. URL: http://www-as.uwyo.edu/ geerts/cwx/notes/chap16/oz_bush.html [Assessed on February, 05, 2021].

Montz B., Tobin G., Hagelman R. (2017). Natural hazards: explanation and integration. The Guilford press, New York, 445.

Noon E.K. (2003). A coupled model approach for assessing fire hazard at point Reyes national seashore: flam map and GIS. Proceedings of the $2^{\text {nd }}$ International wildland fire ecology and fire management congress, Springs Resort.

Oliveira S.L.J., Pereira J.M.C., Carreiras J.M.B. (2012). Fire frequency analysis in Portugal (1975-2005), using Landsat-based burnt area maps. Int. J. Wildland Fire, 21 (1), 48-60, DOI: 10.1071/WF10131.

Parisien M.-A., Snetsinger S., Greenberg J.A., Nelson C.R., Schoennagel T., Dobrowski S.Z., Moritz M.A. (2012). Spatial variability in wildfire probability across the western United States. Int. J. Wildland Fire, 21(4), 313-327. DOI: 10.1071/WF11044.

Preisler H.K., Riley K.L., Stonesifer C.S., Calkin D.E., Jolly W.M. (2016). Near-term probabilistic forecast of significant wildfire events for the Western United States. Int J Wildland Fire, 25 (11), 1169-1180, DOI: 10.1071/WF16038.

Radke J. (1995). Modeling urban/wildland interface fire hazards within a geographic information system, Geographic Information Sciences, 1(1), 9-21.

Rogeau M.-P., Flannigan M.D., Hawkes B.C., Parisien M.-A., Rick A. (2016). Spatial and temporal variations of fire regimes in the Canadian Rocky Mountains and Foothills of southern Alberta. Int. J. Wildland Fire, 25(11), 1117-1130, DOI: 10.1071/WF15120. 
Rubtsova T.A. (2016). Types of Vascular Plants Described from the Territory of the Jewish Autonomous Region as New to Science. Regional Problems, 19(3), 32-37 (in Russian).

Salis M., Arca B., Arianoutsou F., et al. (2016). Predicting wildfire spread and behaviour in Mediterranean landscapes. Int. J. Wildland Fire, 25(10), 1015-1032, DOI: 10.1071/WF15081.

Sheshukov M.A. (1982). Forest fire district of the Far East. Khabarovsk (in Russian).

Sheshukov M.A., Brusova E.V., Gromyko S.A., Pozdnyakova V.V. (2009). Conservation and protection of the forest. In: The current state of the forests of the Russian Far East and the prospects for their use, M.A. Sheshukov (Ed.), Khabarovsk, DalNIILKH, 470. (in Russian).

Sofronov M.A., Volokitina A.V. (1990). Pyrological zoning in the taiga zone. Novosibirsk, 205 (in Russian).

Sommers W.T., Coloff S.G., Conard S.G. (2012). Synthesis of knowledge: fire history and climate change. Final report to the Joint Fire Science Program, JFSP Project 09-02-1-09.

Starodumov A.M. (1965). Scale of fire hazard of plantings and other categories of areas for the conditions of the Far East. Khabarovsk: DalNIILKh (in Russian).

Stephens S.L., Burrows N., Buyantuyev A., Gray R.W., Keane R.E., Kubian R., Liu S., Seijo F., Shu L., Tolhurst K.G., van Wagtendonk J.W. (2014). Temperate and boreal forest mega-fires: characteristics and challenges. Frontier Ecol. Environ., 12(2), 115-122, DOI: 10.1890/120332.

Telitsyn G.P. (1988). Forest fires, their prevention and extinguishing in the Khabarovsky Krai. Khabarovsk, p. 95 (in Russian).

Tian X., Shu L., Wang M., Zhao F., Chen L. (2013a). The fire Danger and Fire Regime for the Daxing'anling Region for 1987-2010. Procedia Engineering, 62, 1023-1031, DOI: 10.1016/j.proeng.2013.08.157.

Tian X., Zhao F., Shu L., Wang M. (2013b). Distribution characteristics and the influence factors of forest fires in China. Forest. Ecol. Management, 310, 460-467, DOI: 10.1016/j.foreco.2013.08.025.

Viegas X.D., Bovio G., Ferreira A., Nosenzo A., Sol B. (1999). Comparative study of various methods of fire danger evaluation in southern Europe. Int. J. Wildland Fire, 9(4), 235-246, DOI: 10.1071/WF00015.

Yi K., Bao Y., Zhang J. (2016). Spatial distribution and temporal variability of open fire in China. Int. J. Wildland Fire, 26 (2), 122-135, DOI: 10.1071/WF15213.

Zubareva A.M. (2016). Fire rate of vegetation in the natural-territorial complexes of the Jewish Autonomous Region, In the book: Modern problems of regional development. Abstracts of the VI International Scientific Conference. Birobidzhan, ICARP FEB RAS, $18-21$ (in Russian).

Zumbrunnen T., Menéndez P., Bugmann H., Conedera M., Gimmi U., Bürgi M. (2012). Human impacts on fire occurrence: a case study of hundred years of forest fires in a dry alpine valley in Switzerland. Reg. Environ. Change, 12 (4), 935-949, DOI: 10.1007/s10113-012-0307-4. 